\title{
Serum levels of HMGB1, survivin, and VEGF in patients with advanced Non-small Cell Lung Cancer during chemotherapy
}

\author{
Wojciech Naumnik ${ }^{1}$, Wiesława Nilklińska² ${ }^{2}$, Maria Ossolińska ${ }^{1}$, \\ Elżbieta Chyczewska ${ }^{1}$
}

\author{
${ }^{1}$ Department of Lung Diseases and Tuberculosis, Medical University of Bialystok, Poland \\ ${ }^{2}$ Department of Histology and Embryology, Medical University of Bialystok, Poland
}

\begin{abstract}
Recently, several reports have suggested that HMGB1 (the high-mobility group box-1) plays a key role in tumor angiogenesis through multiple mechanisms, including up-regulation of proangiogenic factors. This study was conducted to investigate the prognostic role and the effects of chemotherapy on serum (ELISA) angiogenic factors: HMGB1, survivin and VEGF (Vascular Endothelial Growth Factor) in patients with advanced stage non-small cell lung cancer (NSCLC). The study entered 40 patients (31 man) and 15 healthy volunteers (control group). Peripheral blood samples were taken before and after four cycles of chemotherapy. The mean serum HMGB1 and VEGF levels were significantly higher in patients with advanced NSCLC than in controls ( $\mathrm{p}=0.024, \mathrm{p}=0.028$, respectively). The levels of survivin in NSCLC patients were comparable to controls. No correlation was found between HMGB1, survivin and VEGF concentrations and the histological type and staging of lung cancer. Similarly, no correlation was revealed between the concentrations of HMGB1, survivin and VEGF and the effect of chemotherapy. However, in patients with NSCLC, HMGB1 positevely correlated with survivin $(\mathrm{R}=0.814, \mathrm{p}=0.007)$ before chemotherapy, and negatively with VEGF $(\mathrm{R}=-0.841, \mathrm{p}=0.035)$ after chemotherapy. When the cut-off values of serum HMGB1, survivin and VEGF $(2.38 \mathrm{ng} / \mathrm{ml}, 81.92 \mathrm{pg} / \mathrm{ml}, 443.26 \mathrm{pg} / \mathrm{ml}$, respectively) were used, the prognoses of high and low groups were not different. Concluding, patients with NSCLC have a higher serum concentration of HMGB1 and VEGF, while survivin levels are comparable to healthy individuals. In our opinion, determination of HMGB1, survivin and VEGF concentrations has no clinical significance in the prognosis of the survival time in lung cancer.
\end{abstract}

Key words: lung cancer, NSCLC, nonsmall cell lung cancer, chemotherapy, HMGB1, the high-mobility group box-1, survivin, VEGF, vascular endothelial growth factor

\section{Introduction}

The high-mobility group box-1 (HMGB1) protein is present in almost all eukaryotic cells [1]. It was identified in the nucleus and in the cytoplasm of several cells. Within the nucleus, HMGB1 stabilizes nucleosomes and regulates transcription of many genes [2]. As a cytokine-like factor, HMGB1 is secreted by macrophages, mature dendritic cells and natural killer cells in response to injury, infection, or other inflammatory stimuli $[3,4]$. The biological importance of HMGB1 is underscored by its multifunctionality, as

Correspondence: W. Naumnik, Dept. of Lung Diseases and

Tuberculosis, Medical University of Bialystok, 14 Zurawia Str., PL 15-540, Bialystok, Poland; tel./fax.: (+4885) 7324149,

e-mail: naumw@post.pl well as pathologic conditions caused in a man by its deregulation: Alzheimer's Disease [5], arthritis [6], and cancer [7]. HMGB1 release into the extracellular environment is mediated by active and passive mechanisms. The passive release of HMGB1 into the extracellular space occurs during unscheduled cell death, where HMGB1 diffuses out of the leaky membranes of the necrotic cells [8]. In this role, HMGB1 serves as a "necrotic marker" or a damage-associated molecular pattern for recognition by cells of the innate immune system and is a surrogate for the extent of injury, initiating tissue repair [6]. The passive release of HMGB1 is not observed during type I apoptotic cell death, in which HMGB1 is tightly sequestered within apoptotic bodies, thereby preventing its release [6]. Outside the cell, HMGB1 masquerades as a cytokine to activate 
endothelial cells, promoting angiogenesis and extravascular emigration of inflammatory cells and stem cells, thereby initiating inflammation [9]. Several receptors have been identified for HMGB1 including RAGE, TLR2, TLR4, syndecan and a specific receptor-tyrosine phosphatase [10]. The signaling mechanisms and end events of these receptor interactions have not been explained completely yet. A variety of human neoplasms, including breast, colorectal, hepatocellular, pancreatic and lung cancer overexpress HMGB1 [11]. There are no data about serum levels of HMGB1 in lung cancer patients during chemotherapy and only few reports about correlations between HGMB 1 and angiogenic factors determined in serum e.g., VEGF and survivin. A vascular endothelial growth factor (VEGF), apparently the most important angiogenic factor, is a prime regulator of both physiological and pathological angiogenesis in malignancy [12]. Survivin is an unique inhibitor of apoptosis, selectively expressed in most human cancers, but undetectable in normal adult tissues [13]. In addition to its direct role in carcinogenesis, survivin may also play a key role in tumor angiogenesis because it is strongly expressed in endothelial cells during the remodeling and proliferative phase of angiogenesis [14]. Recent studies have also suggested that survivin plays a role in tumor progression and chemoresistance [15].

\section{Materials and methods}

Patients. The study involved 40 patients diagnosed and treated in the Department of Lung Diseases and Tuberculosis in Bialystok (31 men and 9 women) with the histological diagnosis of NSCLC. The mean age of patients was $60.7 \pm 3$ years. The study patients had neither been treated with any anticancer medication nor undergone radiotherapy. Squamous cell carcinoma (SCC) comprised $42.5 \%$ (17 individuals) of patients with NSCLC, adenocarcinoma was revealed in $27.5 \%$ ( 11 patients), whereas NSCLC was diagnosed in $30 \%$ (12 patients). Serum samples obtained from the whole blood of patients with lung cancer before cytoreduction treatment and after four cycles of chemotherapy, were used as the study material. To exclude the possible interference of chemotherapy, subsequent blood samples were obtained at least 28 days after the last administration of cytotoxic drugs. Blood serum was stored at $-80^{\circ} \mathrm{C}$ immediately after separation by centrifugation $(3000 \mathrm{rpm})$ until the assay was performed. At the first stage, blood samples were taken to assess HMGB1, survivin, and VEGF after complete diagnostics of lung cancer had been made, including X-ray and CT of the chest, bronchofiberscopy with H-P test, lung transbronchial biopsy (TBB), or transbronchial needle aspiration biopsy (TBNA). The clinical analysis comprised the evaluation of clinical staging of NSCLC (TNM, AJCC), and the performance stage according to Zubrod. The response to therapy was estimated according to the WHO criteria. All patients underwent basic laboratory tests and accessory investigations (ultrasonography of the abdominal cavity, if necessary, of the chest, EEG, and CT of the central nervous system). At the next stage, after termination of chemotherapy, during the evaluation of therapy outcome, blood samples were collected to determine the concentrations of HMGB1, survivin, and VEGF.

Control subjects. The control group consisted of 15 healthy volunteers (12 men and 3 women) without any acute or chronic inflammatory conditions. The mean age of controls at the time of sampling was $62.1 \pm 4$ years. There were no significant differences in age and sex between patients and controls.

Therapy. Chemotherapy was carried out in a 21-day cycle using cisplatin at a dose of $30 \mathrm{mg} / \mathrm{m}^{2}$ on days 1,2 , and 3 and gemcytabine at a dose of $1000 \mathrm{mg} / \mathrm{m}^{2}$ on days 1 and 8 of the cycle. All patients received four cycles of chemotherapy. Some of the patients underwent later radiotherapy or next cycles of chemotherapy.

Serum HMGB1, survivin, and VEGF analysis. HMGB1 (HMGB1 Elisa Kit II, Shino- Test Corp., Japan), survivin (Quantikine Human survivin Immunoassay, R\&D System, USA), and VEGF (Quantikine Human VEGF Immunoassay, R\&D System, USA) concentrations were determined by means of an enzymelinked immunosorbent assay (ELISA) method according to the manufacturer's instructions. All specimens were assayed twice and the average of the two measurements was used in the data analysis. The minimum detectable dose (MDD) of HMGB1 ranged from 2.5 to $80 \mathrm{ng} / \mathrm{ml}$. The sensitivity was $1.0 \mathrm{ng} / \mathrm{ml}$. The MDD of survivin ranged from $1.58 \mathrm{pg} / \mathrm{ml}$ to $9.96 \mathrm{pg} / \mathrm{ml}$. The mean MDD was $4.44 \mathrm{pg} / \mathrm{ml}$. The MDD of VEGF was less than $5.0 \mathrm{pg} / \mathrm{ml}$.

Ethical issues. In accordance with the declaration of Helsinki, the study protocol was approved by the local ethics committee and written informed consent was obtained from all participants.

Statistical analysis. Statistical analysis was performed using Statistica 8.0 software (Stat Soft Inc., Tulsa, USA). The compatibility test of Shapiro-Wilk was used for measurable features consistent with normal distribution. The Student $t$ test for paired and unpaired samples was applied. Correlations between the parameters were calculated by the Pearson's tests. Survival curves were generated using the Kaplan-Meier method, and the significant difference in survival rates was determined by the log-rank test. Multivariate analysis was performed using the Cox proportional hazards model. All patients with lung cancer were divided into two groups according to their HMGB1, survivin, and VEGF serum levels. The cut-off point was set at $2.38 \mathrm{ng} / \mathrm{ml}$ for HMGB1, $81.92 \mathrm{pg} / \mathrm{ml}$ for survivin, and $443.26 \mathrm{pg} / \mathrm{ml}$ for VEGF. Receiver-operating characteristics (ROC) curves were applied to find the cut-off level of HMGB1, survivin, and VEGF. A value of $p<0.05$ was considered to be the level of statistical significance.

\section{Results}

None of the prognostic parameters analyzed (Table 1) was correlated significantly with the serum HMGB1, survivin and VEGF levels ( $\mathrm{p}>0.05)$.

The levels of serum HMGB1, survivin and VEGF in patients with advanced NSCLC and healthy controls are shown in Table 2. The baseline serum HMGB1 and VEGF levels were significantly higher in patients with advanced NSCLC than in the control group $(\mathrm{p}=0.024$, $\mathrm{p}=0.028$ ). survivin levels were not significantly different from the healthy control group $(p=0.705)$. Concentrations of HMGB1, survivin and VEGF did not differ markedly before and after chemotherapy of lung cancer ( $\mathrm{p}=0.809, \mathrm{p}=0.902$ and $\mathrm{p}=0.409)$ (Table 3$)$. No correlation was found between HMGB1, survivin and VEGF concentrations and the histological type and staging of lung cancer. Patients in group IIIB had the same concentrations of HMGB1, survivin and VEGF as patients in group IV. 
Table 1. Patients' characteristics

\begin{tabular}{|l|c|}
\hline Parameter & $\mathrm{n}$ \\
\hline No. of patients & 40 \\
\hline$\Lambda$ ge, yr mean \pm SD) & $60.7 \pm 3$ \\
\hline Gender, malc//cmale & $31 / 9$ \\
\hline Weight loss (10\%), yes/no & $15 / 25$ \\
\hline Performance stalus, 0-1/2 & $29 / 11$ \\
\hline Histology, squamous cell/other & $17 / 23$ \\
\hline Stage, IIIB//V & $21 / 19$ \\
\hline Ilacmoglobin (12g/d1), low/normal & $11 / 29$ \\
\hline$\Lambda$ lbumin (3.5 g/dl), low/normal & $4 / 36$ \\
\hline LDIl (450 U/L), normal, clevaled & $25 / 15$ \\
\hline Response to chemotherapy, yes/no & $26 / 14$ \\
\hline
\end{tabular}

Abbreviations: $\mathrm{n}$ - number; $\mathrm{SD}$ - standard deviation

Table 2. Distribution of serum HMGB1, Survivin and VEGF values in patients with NSCLC and healthy controls by student's $\mathrm{t}$ - test for unpaired samples.

\begin{tabular}{|c|c|c|c|}
\hline & $\begin{array}{c}\text { Patients } \\
(\mathrm{n}=40) \\
\text { mean } \pm \mathrm{SD})\end{array}$ & $\begin{array}{c}\text { Controls } \\
(\mathrm{n}=15) \\
\text { mean } \pm \mathrm{SD})\end{array}$ & $\mathrm{p}$ \\
\hline $\begin{array}{c}\text { IIMGBl } \\
(\mathrm{ng} / \mathrm{ml})\end{array}$ & $2.75 \pm 0.7$ & $2.08 \pm 0.3$ & 0.024 \\
\hline $\begin{array}{c}\text { Survivin } \\
(\mathrm{pg} / \mathrm{ml})\end{array}$ & $63.25 \pm 36.2$ & $69.62 \pm 12.3$ & 0.705 \\
\hline $\begin{array}{c}\mathrm{VLGi} \\
(\mathrm{pg} / \mathrm{ml})\end{array}$ & $\begin{array}{c}645.71 \pm \\
183.7\end{array}$ & $378.66 \pm 64.6$ & 0.028 \\
\hline
\end{tabular}

Abbreviations: $\mathrm{n}$ - number; $\mathrm{SD}$ - standard deviation

Table 3. Distribution of serum values of HMGB1, Survivin and VEGF in patients with NSCLC before and after chemotherapy disease by Student's $\mathrm{T}$ - test for paired samples.

\begin{tabular}{|c|c|c|c|}
\hline & $\begin{array}{c}\text { Before } \\
\text { chemotherapy } \\
\text { mean } \pm \mathrm{SD})\end{array}$ & $\begin{array}{c}\text { After } \\
\text { chemotherapy } \\
\text { mean } \pm \mathrm{SD}\end{array}$ & $\mathrm{p}$ \\
\hline $\begin{array}{c}\text { ILMGiBl } \\
(\mathrm{ng} / \mathrm{ml})\end{array}$ & $2.75 \pm 0.7$ & $2.73 \pm 0.7$ & 0.809 \\
\hline $\begin{array}{c}\text { Survivin } \\
(\mathrm{pg} / \mathrm{ml})\end{array}$ & $63.25 \pm 36.2$ & $60.20 \pm 23.3$ & 0.902 \\
\hline $\begin{array}{c}\mathrm{VLGil} \\
(\mathrm{pg} / \mathrm{ml})\end{array}$ & $645.71 \pm 183.7$ & $688.67 \pm 113.5$ & 0.409 \\
\hline
\end{tabular}

Abbreviations: $\mathrm{n}$ - number; $\mathrm{SD}$ - standard deviation

In the group of patients, PR (Partial Response) was reported in 16 patients $(40 \%)$, stabilization $(\mathrm{NC}, \mathrm{No}$ Change) in 10 patients $(25 \%)$, and PD (Progressive Disease) in 14 patients (35\%). No correlation was found between the concentrations of HMGB1, survivin and VEGF and the effect of chemotherapy (Tables 4 and 5).

A positive correlation between HMGB1 and survivin concentrations $(\mathrm{R}=0.814, \mathrm{p}=0.007)$ in patients with lung cancer before treatment; a negative corre-
Table 4. Distribution of serum values of HMGB1, survivin and VEGF before and after chemotherapy, in patients with partial response or stable disease by student's $t$ - test for paired samples (subgroup analysis).

\begin{tabular}{|c|c|c|c|}
\hline & $\begin{array}{c}\text { Before } \\
\text { chemotherapy } \\
\text { mean } \pm \mathrm{SL})\end{array}$ & $\begin{array}{c}\text { After } \\
\text { chemotherapy } \\
\text { mean } \pm \mathrm{SD}\end{array}$ & $\mathrm{p}$ \\
\hline $\begin{array}{c}\mathrm{IIMGiBl} \\
(\mathrm{ng} / \mathrm{ml})\end{array}$ & $2.67 \pm 0.8$ & $2.75 \pm 0.9$ & 0.700 \\
\hline $\begin{array}{c}\text { Survivin } \\
(\mathrm{pg} / \mathrm{ml})\end{array}$ & $57.38 \pm 32.3$ & $55.60 \pm 23.7$ & 0.718 \\
\hline $\begin{array}{c}\mathrm{VLGil} \\
(\mathrm{pg} / \mathrm{ml})\end{array}$ & $699.73 \pm 243.3$ & $725.72 \pm 113.5$ & 0.771 \\
\hline
\end{tabular}

Abbreviations: $\mathrm{n}$ - number; $\mathrm{SD}$ - standard deviation

Table 5. Distribution of serum values of HMGB1, Survivin and VEGF before and after chemotherapy, in patients with progressive disease by student's $\mathrm{t}$ - test for paired samples (subgroup analysis).

\begin{tabular}{|c|c|c|c|}
\hline & $\begin{array}{c}\text { Before } \\
\text { chemotherapy } \\
\text { mean } \pm \text { SD }\end{array}$ & $\begin{array}{c}\wedge \text { fter } \\
\text { chemotherapy } \\
\text { mean } \pm \text { SD }\end{array}$ & $p$ \\
\hline $\begin{array}{c}\text { HMGB1 } \\
(\mathrm{ng} / \mathrm{ml})\end{array}$ & $2.87 \pm 0.7$ & $2.73 \pm 0.8$ & 0.320 \\
\hline $\begin{array}{c}\text { Survivin } \\
(\mathrm{pg} / \mathrm{ml})\end{array}$ & $74.52 \pm 41.9$ & $68.6 \pm 21.1$ & 0.454 \\
\hline $\begin{array}{c}\mathrm{VF}(\mathrm{FF} \\
(\mathrm{pg} / \mathrm{ml})\end{array}$ & $564.6 \pm 183.2$ & $633.0 \pm 118.0$ & 0.424 \\
\hline
\end{tabular}

Abbreviations: $\mathrm{n}$ - number; $\mathrm{SD}$ - standard deviation

lation between HMGB1 and VEGF concentrations $(\mathrm{R}=-0.841, \mathrm{p}=0.035)$ in patients with lung cancer after treatment were found.

When all patients with lung cancer were divided into high and low groups using cut-off serum HMGB1, survivin and VEGF concentrations, the prognoses of high and low groups were not different. The cut-off serum concentrations were $2.38 \mathrm{ng} / \mathrm{ml}$ for HMGB1 (Fig. 1), $81.92 \mathrm{pg} / \mathrm{ml}$ for survivin (Fig. 2) and 443.26 $\mathrm{pg} / \mathrm{ml}$ for VEGF (Fig. 3). The mean survival time of all patients was 11.3 months. Older age, weight loss, and performance status yielded a prognostic value $(p=0.023$, $\mathrm{p}=0.001, \mathrm{p}=0.002$, respectively) (Table 6). Conversely, neither HMGB1, survivin nor VEGF levels were proved to be significant for the survival time.

ROC (Receiver Operating Characteristic) curve analysis was performed to assess the effectiveness of serum HMGB1 and VEGF determination used to discriminate between NSCLC and controls (Fig. 4). The AUCs of HMGB1, survivin and VEGF were respectively: $0.763,0.764,0.752$ and all of them were higher than $0.5(\mathrm{p}=0.035 ; \mathrm{p}=0.021 ; \mathrm{p}=0.012)$. ROC curves showed that circulating HMGB1 and VEGF serum level did not demonstrate a high sensitivity-specificity relationship, and therefore, had a 

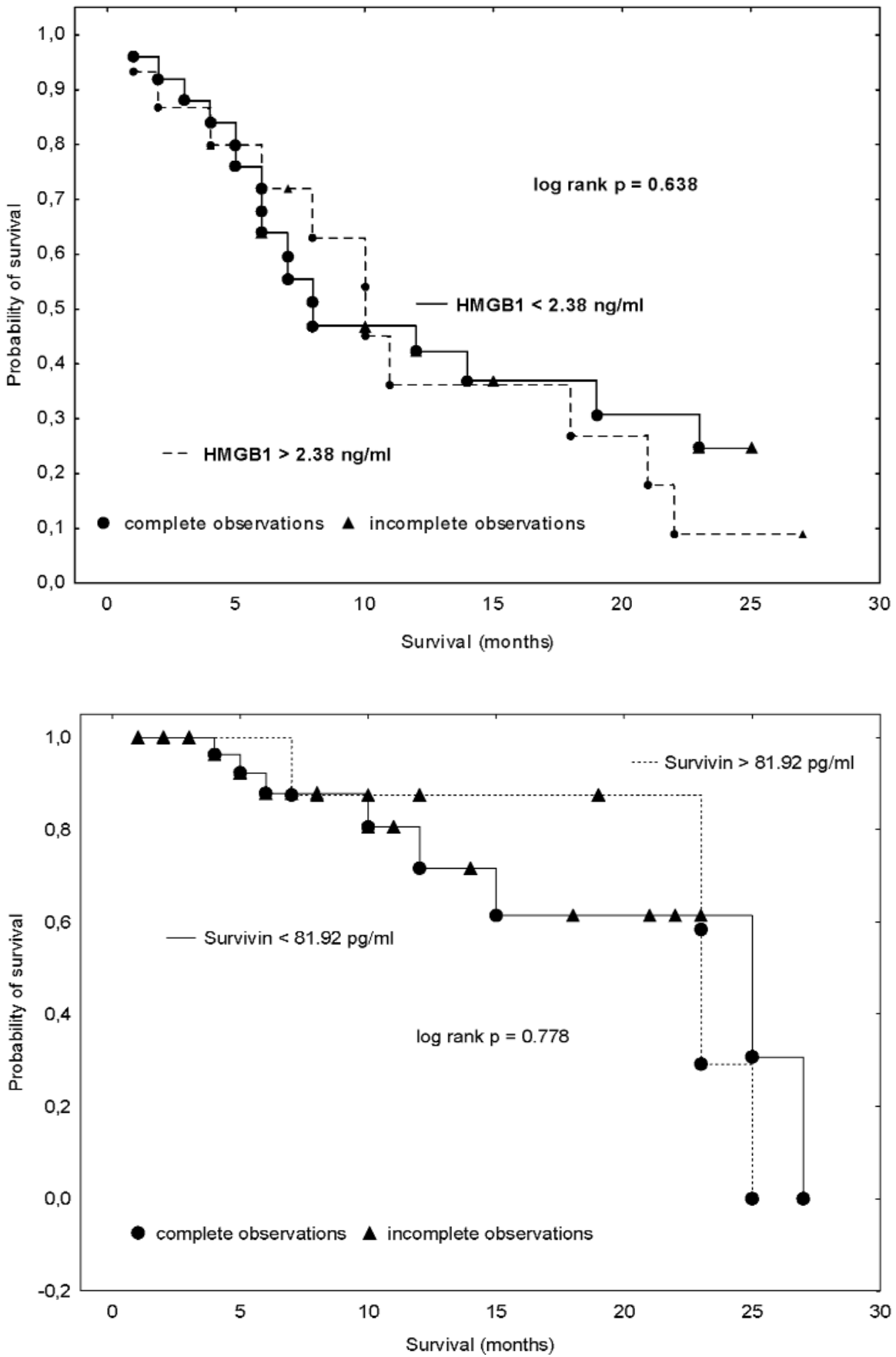

Fig. 1. Probability of survival for lung cancer patients in relation to serum HMBG1 levels (before chemotherapy).
Fig. 2. Probability of survival for lung cancer patients in relation to serum Survivin levels (before chemotherapy).
Table 6. Influence of statistically significant prognostic factors and serum parameters on survival in advanced NSCLC patients

\begin{tabular}{|l|c|}
\hline \multicolumn{1}{|c|}{ Prognostic factor } & p value \\
\hline ^ge & 0.023 \\
\hline Weight loss & 0.001 \\
\hline Performance status & 0.002 \\
\hline Scrum IIMGiB l & 0.721 \\
\hline Scrum Survivin & 0.532 \\
\hline Scrum VLGl & 0.342 \\
\hline
\end{tabular}

low ability to differentiate NSCLC from healthy persons. The cut off values of HMGB1, survivin and VEGF were established at $1.75 \mathrm{ng} / \mathrm{ml} ; 156.7 \mathrm{pg} / \mathrm{ml}$; $307.64 \mathrm{pg} / \mathrm{ml}$ (ROC curves), respectively. There were no significant differences between the areas under the curves.

\section{Discussion}

Neoangiogenesis plays a key role in a tumor's growth. VEGF as well as survivin and HMGB1, described 


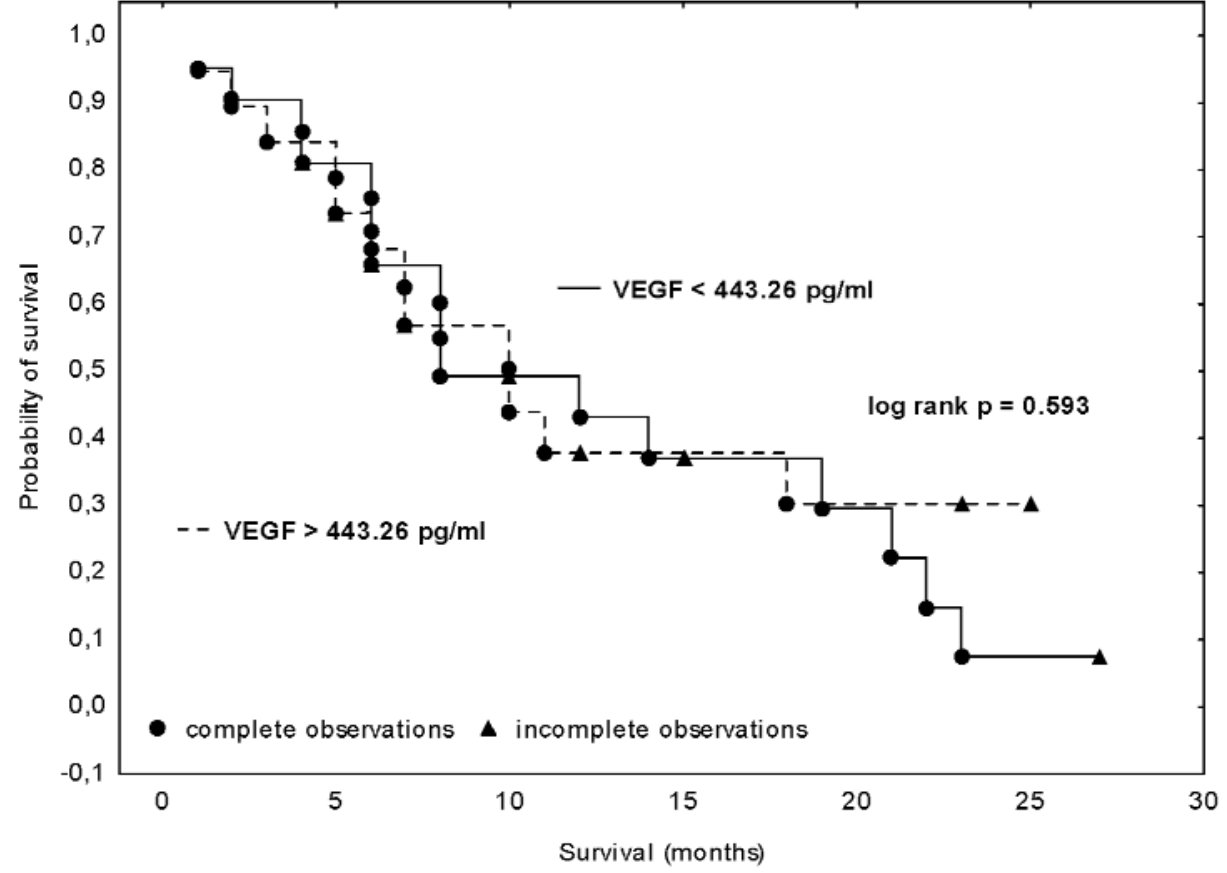

Fig. 3. Probability of survival for lung cancer patients in relation to serum VEGF levels (before chemotherapy).

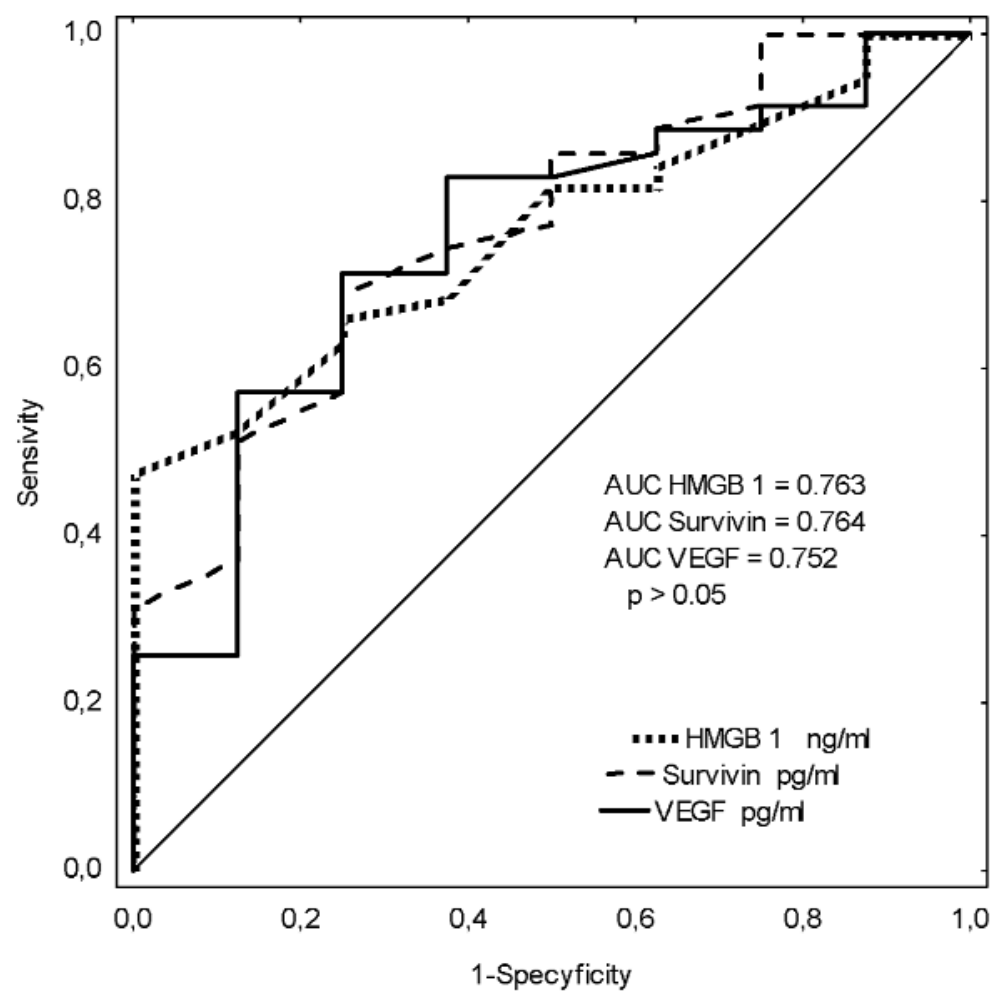

Fig. 4. ROC curves of HMGB 1, survivin and VEGF (for discrimination between NSCLC and controls). lately are the most important growth factors involved in this process. Recently, several reports have suggested that HMGB1 plays a key role in tumor angiogenesis through multiple mechanisms, including up-regulation of proangiogenic factors, promoting endothelial progenitor cells homing to ischemic tumor tissues and induction of endothelial cell migration and sprouting
[16]. The correlations between serum concentrations: HMGB1 and survivin as well as HMGB1 and VEGF, obtained in our study, demonstrate mutual inter-relations between angiogenic factors mentioned above.

Hypoxia is a common phenomenon in human solid tumors as a result of the rapid growth rate of the tumor cells [16]. Chronic hypoxia often leads to necrotic 
regions, in which HMGB1 rapidly leaks out from permeable necrotic tumor cells. Meanwhile, tumor-associated macrophages accumulated in the hypoxic tumor regions could be activated by HMGB1, resulting in secretion of angiogenic factors, including a vascular endothelial growth factor (VEGF), and thereby promoting tumor angiogenesis [17]. Thus, patients with lung cancer have the higher concentration of VEGF in serum, which was confirmed in our study and by many other researchers [18]. The high circulating serum vascular endothelial growth factor (VEGF) levels might reflect enhanced angiogenesis in patients suffering from non-small cell lung cancer (NSCLC).

In the study, it was proved for the first time that patients with lung cancer had the higher serum concentration of HMGB1 than healthy people. The studies to date on HMGB1 in patients with lung cancer concerned explicitly the expression in tumor tissues.

HMGB1 binds RAGE (receptor for advanced glycation end products) receptor to initiate many cellular processes [17]. Non-small cell carcinoma studies established a role for RAGE in the regulation of differentiation in the lung tissue characterized by downregulation of RAGE [19]. The loss of HMGB1-RAGE -mediated regulation of tumor cell migration and invasive processes are associated with increased aggressiveness of tumor behavior in the lung $[19,20]$.

The lower involvement of HGMB1 in binding with RAGE receptor may contribute to the growth of this protein in blood serum, which is in accordance with the results of our study. Patients with NSCLC had higher concentrations of HMGB1 than healthy people. However, active myeloid cells, NK cells and cytotoxic $\mathrm{T}$ cells secreted from macrophages and monocytes may contribute to the growth of this protein (during anti-neoplastic T-cell responses) [21]. Apoptosis also contributes to an increase in HMGB1 serum concentration - a massive 'throw' of HMGB1 from the decomposition of tumor cells, present previously in the nucleus and cytoplasm.

One of the inhibitors of apoptosis is survivin. It also promotes cell proliferation and induces angiogenesis [22]. survivin shows a significant difference in the expression between malignant and normal adult cells, with very low to absent levels in the normal adult tissue but increased levels in a wide variety of solid tumors [23]. In tumors, the positive expression of survivin correlates with more aggressive behavior and poorer prognosis [24]. Our study based on the measurements of survivin concentrations in serum did not confirm these observations. We proved that survivin concentrations were the same in patients with NSCLC as in healthy people and were not related to the prognosis of survival time. These results were in agreement with Fan's et al. findings [25] and studies among patients with other cancers [26].
Similarly, we indicated that determination of serum concentrations of HGMB1 during chemotherapy was useless for the prognosis of survival time and the effect of chemotherapy. In patients with colorectal cancer, the enhanced expression of HMGB1 was proved to correlate with poor prognosis [27].

A lack of correlations between HMGB1 concentrations and survival time, staging and an effect of chemotherapy may be due to complex mechanisms and interrelations that cause HMGB1 release to the blood. On the one hand, these are mechanisms responsible for cell death (apoptosis, autophagy, necrosis), on the other, the reaction of inflammatory cells and the immune system to the growing tumor [1].

Besides endothelial cells, VEGF is secreted by several cell types such as, macrophages, stromal cells, epithelial cells of the retina, and malignant cells [28]. Nevertheless, hypoxia is not the only cause of VEGF production by a tumor [28]. The increased VEGF gene expression has also been reported after inactivation of p53 or RAS mutations, and after expression of the oncogene $\operatorname{Src}$ [29]. The tumor angiogenesis can also be regulated by various exogenous factors which modulate the VEGF production, thereby exercising an indirect angiogenic effect [28]. These complex mechanisms influencing serum VEGF concentration might have contributed to the fact that we did not prove correlations between VEGF concentrations, and the effect of therapy and prognosis of survival time. The results of our study are in accordance with Chakra's et al.[30] and Tas's et al [31] findings. These authors proved that a circulating serum vascular endothelial growth factor was not a prognostic factor of non-small cell lung cancer. Conversely, Dudek et al [18] found the correlation between the concentration of VEGF and the treatment response and survival time and high levels of serum VEGF at the time of presentation with NSCLC might predict worse survival.

Summing up, patients with lung cancer have a higher serum concentration of HMGB1 and VEGF in comparison with healthy people. The levels of survivin in serum of NSCLC patients are comparable to this of healthy people. In our opinion, determination of HMGB1, survivin and VEGF concentrations has no clinical significance in the prognosis of the survival time in lung cancer.

\section{References}

[1] Ellerman JE, Brown CK, De Vera M, Zeh HJ, Billiar T, Rubartelli A, Lotze MT. Masquerader: HighMobility Group Box-1 and Cancer. Clin Cancer Res. 2007;13:2836-2848.

[ 2] Park JS, Arcaroli J, Yum HK, Yang H, Wang H, Yang KY, Choe KH, Strassheim D, Pitts TM, Tracey KJ, Abraham E. Activation of gene expression in human neutrophils by high mobility group box 1 protein. Am J Physiol Cell Physiol. 2003;284:C870-9. 
[ 3] Bonaldi T, Talamo F, Scaffidi P, Ferrera D, Porto A, Bachi A, Rubartelli A, Agresti A, Bianchi ME. Monocytic cells hyperacetylate chromatin protein HMGB1 to redirect it towards secretion. EMBO J. 2003;22:5551-5560.

[4] Semino C, Angelini G, Poggi A, Rubartelli A. NK/iDC interaction results in IL-18 secretion by DCs at the synaptic cleft followed by NK cell activation and release of the DC maturation factor HMGB1. Blood. 2005;106:609-616.

[ 5] Takata K, Kitamura Y, Kakimura J, Shibagaki K, Tsuchiya D, Taniguchi T, Smith MA, Perry G, Shimohama S. Role of high mobility group protein-1 (HMG1) in amyloid-beta homeostasis. Biochem Biophys Res Commun. 2003;301:699-703.

[6] Ulloa L, Messmer D. High-mobility group box 1 (HMGB1) protein: Friend and foe. Cytokine Growth Factor Rev. 2006;17:189-201.

[7] Lotze MT,Tracey KJ. High-mobility groupbox 1 protein (HMGB1): nuclear weapon in the immune arsenal. Nat Rev Immunol. 2005;5:331-342.

[ 8] Zeh HJ 3rd, Lotze MT. Addicted to death: invasive cancer and the immune response to unscheduled cell death. $J$ Immunother. 2005;28:1-9.

[9] Rovere-Querini P, Capobianco A, Scaffidi P, Valentinis B, Catalanotti F, Giazzon M, Dumitriu IE, Müller S, Iannacone M, Traversari C, Bianchi ME, Manfredi AA. HMGB1 is an endogenous immune adjuvant released by necrotic cells. EMBO Rep. 2004;8:825-830.

[10] Yuan F, Gu L, Guo S, Wang C, Li GM. Evidence for involvement of HMGB1 protein in human DNA mismatch repair. $J$ Biol Chem. 2004;279:20935-20940.

[11] Lotze MT, Zeh HJ, Rubartelli A, Sparvero LJ, Amoscato AA, Washburn NR, Devera ME, Liang X, Tor M and Billiar T. The grateful dead: damage-associated molecular pattern molecules and reduction/oxidation regulate immunity. Immunol Rev. 2007;220:60-81.

[12] Veikkola T, Alitalo K. VEGFs, receptors and angiogenesis. Semin Cancer Biol. 1999;9:211-220.

[13] Mita AC, Mita MM, Nawrocki ST, Giles FJ. Survivin: key regulator of mitosis and apoptosis and novel target for cancer therapeutics. Clin Cancer Res. 2008;14:5000-5005.

[14] Tran J, Rak J, Sheehan C, Saibil SD, LaCasse E, Korneluk RG, Kerbel RS. Marked induction of the IAP family antiapoptotic proteins survivin and XIAP by VEGF in vascular endothelial cells. Biochem Biophys Res Commun. 1999;264:781-788.

[15] Ambrosini G, Adida C, Altieri DC. A novel antiapoptosis gene, survivin, expressed in cancer and lymphoma. Nat Med. 1997;3:917-921.

[16] Cai-Lian Zhang, Mao-Guo Shu, Hao-Wen Qi, Li-Wen Li. Inhibition of tumor angiogenesis by HMGB1 A box peptide. Medical Hypotheses. 2008;70:343-345.

[17] Schlueter C, Weber H, Meyer B, Rogalla P, Röser K, Hauke $\mathrm{S}$, Bullerdiek J. Angiogenetic signaling through hypoxia: HMGB1: an angiogenetic switch molecule. Am J Pathol. 2005;166:1259-1263.
[18] Dudek AZ, Mahaseth H. Circulating angiogenic cytokines in patients with advanced non-small cell lung cancer: correlation with treatment response and survival. Cancer Invest. 2005;23:193-200.

[19] Bartling B, Hofmann HS, Weigle B, Silber RE, Simm A. Down-regulation of the receptor for advanced glycation endproducts (RAGE) supports non-small cell lung carcinoma. Carcinogenesis. 2005;26:293-301.

[20] Huttunen HJ, Fages C, Kuja-Panula J, Ridley AJ, Rauvala H. Receptor for advanced glycation end products-binding $\mathrm{COOH}$-terminal motif of amphoterin inhibits invasivemigration and metastasis. Cancer Res. 2002;62:4805-4811.

[21] Campana L, Bosurgi L, Rovere-Querini P. HMGB1: a twoheaded signal regulating tumor progression and immunity. Curr Opinion Immunol. 2008;20:518-523.

[22] Margulis V, Lotan Y, Shariat SF. Survivin: a promising biomarker for detection and prognosis of bladder cancer. World $J$ Urol. 2008;26:59-65.

[23] Li F, Ling X. survivin study: an update of "what is the next wave"? J Cell Physiol. 2006;208:476-486.

[24] Altieri DC. Validating survivin as a cancer therapeutic target. Nat Rev Cancer. 2003;3:46-54.

[25] Fan J, Wang L, Jiang GN, He WX, Ding JA. The role of survivin on overall survival of non-small cell lung cancer, a meta-analysis of published literatures. Lung Cancer. 2008;61:91-96.

[26] Goksel G, Taneli F, Uslu R, Ulman C, Dinc G, Coskun T, Kandiloglu AR. Serum her-2/neu and survivin levels and their relationship to histological parameters in early-stage breast cancer. J Int Med Res. 2007;35:165-172.

[27] Sasahira T, Akama Y, Fujii K, Kuniyasu H. Expression of receptor for advanced glycation end products and HMGB1/amphoterin in colorectal adenomas. Virchows Arch. 2005;446:411-415.

[28] Bremnes RM, Camps C, Sirera R. Angiogenesis in non-small cell lung cancer: the prognostic impact of neoangiogenesis and the cytokines VEGF and bFGF in tumours and blood. Lung Cancer. 2006;51:143-158.

[29] Mukhopadhyay D, Tsiokas L, Sukhatme VP. Wild-type p53 and $\mathrm{v}$-Src exert opposing influences on human vascular endothelial growth factor gene expression. Cancer Res. 1995;55:6161-6165.

[30] Chakra M, Pujol JL, Lamy PJ, Bozonnat MC, Quantin X, Jacot W, Daur?s JP. Circulating serum vascular endothelial growth factor is not a prognostic factor of non-small cell lung cancer. $J$ Thorac Oncol. 2008;10:1119-1126.

[31] Tas F, Duranyildiz D, Oguz H, Camlica H, Yasasever V, Topuz E. Serum vascular endothelial growth factor (VEGF) and bcl-2 levels in advanced stage non-small cell lung cancer. Cancer Invest. 2006;24:576-580.

Submitted: 25February, 2009 Accepted after reviews: 15 May, 2009 